\title{
Fish as Bioindicator: Ecological Risk Assessment of Insecticide to Aquatic Organism Particularly Ctenopharyngodon idella
}

\author{
Naqash Khan', Aamir Sultan1, Amir Ali', Sahibzada Muhammad Haseeb Jan', \\ Waqar Khan', Ihtisham Ur Rahman', Hazrat Usman'1, Suleman', Zahid Khan', Ahsan Khan1,2* \\ ${ }^{1}$ Department of Zoology, University of Swabi, Anbar, Swabi, Khyber Pakhtunkhwa, Pakistan \\ ${ }^{2}$ Department of Zoology, University of Peshawar, Khyber Pakhtunkhwa, Pakistan \\ Email: *Ahsanyousafzai27@yahoo.com
}

How to cite this paper: Khan, N., Sultan, A., Ali, A., Jan, S. M. H., Khan, W., Rahman, I. U., Usman, H., Suleman, Khan, Z., \& Khan, A. (2021). Fish as Bioindicator: Ecological Risk Assessment of Insecticide to Aquatic Organism Particularly Ctenopharyngodon idella. Journal of Geoscience and Environment Protection, 9, 42-54. https://doi.org/10.4236/gep.2021.92003

Received: November 26, 2020

Accepted: February 5, 2021

Published: February 8, 2021

Copyright $\odot 2021$ by author(s) and Scientific Research Publishing Inc. This work is licensed under the Creative Commons Attribution International License (CC BY 4.0).

http://creativecommons.org/licenses/by/4.0/ (c) (i) Open Access

\begin{abstract}
Repeatedly deposition of anthropogenic chemicals such as chlorpyrifos led to the risk of its associated unwanted toxicity to the non-targeted organisms. The present project was designed to assess the toxicity of chlorpyrifos, an organophosphorus insecticide, at different dose level and duration of exposure to elucidate its cellular and nuclear anomalies in erythrocytes and histopathological effect on brain and liver tissues of the fresh water fish (Ctenopharyngodon idella). The chlorpyrifos was used at 0.01 and 0.015 $\mu \mathrm{L} / \mathrm{L}$ for a duration of $3,6,9,12$, and 15 days respectively. Alteration in functional markers such as cellular anomalies associated with exposed dosage was reported as swollen cells, swollen or enlarged cells, and hemolyzed cells followed by nuclear abnormalities stated as micronucleus, deformed nucleus and nuclear shift. The result indicated alterations observed in brain and liver tissues were categorized as necrosis, vacuolization, degeneration of neurons and hepatic necrosis, hepatolysis and hepatic vacuolization that were further scored on the basis of severity from 0 (normal) to 3 (severe). These effects significantly increased with the increase in dose level of chlorpyrifos and duration of exposure $(p<0.05)$. The present findings contributed that extended exposure of such chemicals to the aquatic ecosystems led to behavioral and histopathological alterations that may result in loss of normal functioning of the organs.
\end{abstract}

\section{Keywords}

Histopathological, Toxicological, Cellular Abnormalities, Nuclear Abnormalities, Organophosphorus, Chlorpyrifos 


\section{Introduction}

Environmental pollution has turned out to be an alarming concern not only in developing nations but in industrialized states as well (Kazi et al., 2009; Ozden, 2010). Fulfilling the needs of the people led to advancement in the industrialization and green revolution that ends in clusters of environmental problems, causing deleterious impact on aquatic ecosystem (McGlashan \& Hughies, 2001). Chemical pollutants resulting from industrial and agriculture activities leaches out into groundwater as well as neighboring water bodies resulting in water contamination (Stalin et al., 2019).

Pakistan, being the industrial and agricultural country, the runoffs from these bodies directly or indirectly discharge into various aquatic bodies; streams, lakes, ponds, river etc. This discharge contains masses of infectious pathogens, oil, hydrocarbon, radioactive substances, heavy metals, pesticides, herbicides and diverse destructive substance such as acids and bases (Samantha et al., 2005). Around 70,000 anthropogenic chemicals are discharged into the water ecosystems (Metzler \& Erica, 2001; Sumpter, 2002).

Amongst various pollutants, chlorpyrifos ( $\mathrm{CPF}$ ) is an organophosphorus insecticide which is extensively utilized in gardens, homes, veterinary and agriculture practices. Few countries use the same insecticide as water larvicide in order to control the mosquito larva (Faheem \& Khlid, 2017). Because of the excessive use of these chemicals, they finally reach lakes, rivers and other water systems because of direct application or through wind and rains (McGlashan \& Hughies, 2001). Such excessive use of these chemicals in the aquatic systems led to adverse effects on the other non-target organisms such as fish (Majumder \& Kaviraj, 2019).

In order to assess the quality of aquatic ecosystem, fish is considered to be of importance as bioindicator to test the ecological integrity (Faggio et al., 2014; Gobi et al., 2018). The insecticide, chlorpyrifos, has been documented to cause severe dysfunctions in fresh water fish such as genotoxicity, hepatic dysfunction and neurochemical (Jiraungkoorskula et al., 2002) and neurobehavioral (Ramah, 2011) changes through various mechanisms. The incidence of chlorpyrifos in the aquatic system with its associated deleterious effects proposes it as an appropriate candidate for analyzing the effects of organophosphate on aquatic fauna (Oruç, 2012).

Chemical induced toxicity at erythrocyte cellular level is an important indicator for assessing their adversity while erythrocyte micronucleus assay is proven and sensitive indictor of DNA damage. Cellular and nuclear abnormalities are further categorized as deformed cells (dc), swollen/enlarge cell (sc), hemolyzed cells (hc) and micronucleus (mn), deformed nucleus (dn), nuclear shift (ns), respectively (Ali et al., 2008; Anbumani \& Mary, 2011).

Histopathology is a term used to describe microscopic investigation of tissues for the elucidation of a disease or damage. Toxicological histopathology provides meaningful information regarding changes associated with use of toxic chemi- 
cals such as pesticides at the tissue level (Velmurugan et al., 2007; Tripathi et al., 2011). All the tissues and organs in the body of an animal may be potential targets for the toxic effects of any chemical compound such as a pesticide (Velmurugan et al., 2009a; Velmurugan et al., 2009b; Lakshmaiah, 2017).

Brain and liver tissues constitute the most important organs of vertebrates, because of their role in controlling and maintaining the most important activities of life such as detoxification, metabolism, excretion and respiration. Pesticides harmfully affected the activities and morphology of these organs as well as interrupt the usual functioning of all the animals ( $\mathrm{Au}, 2004$; Giari et al., 2008; Velmurugan et al., 2007). Histopathological alterations in the functioning of liver, eyes, brain and gills of variety of fish have been studied (Pal et al., 2012; Topal et al., 2014; Zahran et al., 2018). Fish are one of the most generally appropriated organism in a aquatic ecosystem and being helpless to natural tainting may reflect the degree of the organic impacts of ecological contamination in waters. Keeping in view the above stated facts, the present study was designed to assess the deleterious effect of chlorpyrifos on fresh water fish grass carp (Ctenopharyngodon idella) as bioindicator of the aquatic ecosystem, and analyzing cellular and nuclear abnormalities in erythrocyte as well as histopathology of brain and liver tissues.

\section{Materials and Methods}

\subsection{Chemical and Study Duration}

Insecticide selected for this study is chlorpyrifos $\left(\mathrm{C}_{9} \mathrm{H}_{11} \mathrm{Cl}_{3} \mathrm{NO}_{3} \mathrm{PS}\right)$ that is extensively used in agricultures, residential and commercials settings to kills numbers of pests include insects and worms. The proposed study was designed to assess the toxicological impact of chlorpyrifos at two dose levels i.e. 0.01 and 0.015 $\mu \mathrm{L} / \mathrm{L}$ for a duration of $3,6,9,12$ and 15 days respectively in grass carp (Ctenopharyngodon idella) and the present study was carried out in Department of Zoology, University of Swabi.

\subsection{Test Animal}

Healthy and uniform size seeds of grass carp, average body size and weight 3.23 $\pm 0.34 \mathrm{~g}$ were purchased and transported in oxygenated bags from Peshawar and Mardan carp hatchery to Fisheries and Aquaculture laboratory, Department of Zoology, University of Swabi. The fish were acclimatized for two weeks before the start of the experiment. During acclimatization, water was changed on a daily basis and fish were offered $40 \%$ protein diet at $5 \%$ body weight. Other water quality parameters were also checked on every alternated day during the experimentation and were found in permissible limits as per recommended value of APHA and American Public Health (APHA, 1998).

\subsection{Sample Collection}

After stipulated time three fish from every aquarium in the control and treated 
group were captured with a hand net and sacrificed. Blood was collected from caudal vein and were stored in EDTA tube while liver brain tissues were removed by decapitation and placed in sera (absolute alcohol, formaldehyde and glacial acetic acid in 6:3:1 ratio) for the further histology process and all samples were stored at $-20^{\circ} \mathrm{C}$ before analysis.

\subsection{Cellular and Nuclear Anomalies Analysis}

Blood drop was drag on the cleaned slide to obtain this smear of blood and then was fixed in methanol for $20 \mathrm{~min}$ after drying. The slides were air dried and stained with Giemsa staining (6\%) for $25 \mathrm{~min}$, washed with tap water, allowed to dried and examined at 100× magnification under microscope (Nikon with DS-L3 camera) for the observation of erythrocyte cellular and nuclear anomalies (DNA damage as micronucleus) that was calculated with the help of given formula.

$$
\text { Cell and nucleus abnormalities }=\frac{\text { Number of cells and nucleus }}{\text { total number of cells and nucleus }} \times 100
$$

\subsection{Histopathological Parameter}

Bell et al. (2000)'s method was adopted for the preservation of tissues and preparation of slides for histopathological assessment. Brain and liver tissues were preserved in $10 \%$ formalin for histologic studies. The preserved tissues were processed in various grades of ethanol, cleared in xylene and impregnated with wax $\left(\mathrm{mp} ; 58^{\circ} \mathrm{C}\right)$. Five microns thick sections were cut using rotary microtome (Leica RM 2165) at 100x. Tissues sections were stained with hematoxylin and eosin ( $\mathrm{H} \& \mathrm{E})$. Stained slides were observed and photographed under high resolution microscope (Lecia, Japan) fitted with a digital camera.

\subsection{Statistical Analysis}

All the analysis of cellular and nuclear abnormalities were performed in triplicates and repeated three times. Data was analyzed using analysis of variance (ANOVA) and expressed as mean value \pm standard deviation. Tukey's honest significant difference test was conducted to assess significant differences among experimental mean values $(p<0.05)$ (Steel et al., 1997).

\section{Results and Discussion}

\subsection{Cellular and Nuclear Damages}

Cellular and nuclear anomalies against both concentrations of chlorpyrifos i.e. $0.01 \mu \mathrm{L} / \mathrm{L}$ and $0.015 \mu \mathrm{L} / \mathrm{L}$ for fish 1,2 and 3 at 3, 6, 9, 12 and 15 days are presented in Table 1, Table 2 and Figure 1, Figure 3 respectively. It was evidenced from statistical analysis that, treatment gad a momentous effect on deformed cells while days and the interaction of both depicted non-significant effect. For swollen cells, treatment, days and their interaction had a momentous effect on the resultant cells. Similar results were obtained for hemolyzed cells as presented in Table 1. As far as the nuclear abnormalities are concerned, micronucleus and deformed 
Table 1. Showing the erythrocytes cells $(\% \pm \mathrm{SD})$ of fish observed against chlorpyrifos $(0.01 \mu \mathrm{L} / \mathrm{L} \mathrm{T} 1,0.015 \mu \mathrm{L} / \mathrm{L}$ T2) exposure for $3,6,9,12$ and 15 days.

\begin{tabular}{|c|c|c|c|c|c|c|c|}
\hline & & \multicolumn{5}{|c|}{ Days } & \multirow{2}{*}{ Mean } \\
\hline & & 3 & 6 & 9 & 12 & 15 & \\
\hline \multirow{3}{*}{ Deformed cells } & $\mathrm{T} 1$ & $8.75 \pm 1.74^{\mathrm{a}}$ & $7.38 \pm 1.90^{\mathrm{a}}$ & $8.94 \pm 1.13^{\mathrm{a}}$ & $10.20 \pm 0.24^{\mathrm{a}}$ & $10.09 \pm 1.25^{\mathrm{a}}$ & $9.072 \pm 1.25^{\mathrm{a}}$ \\
\hline & $\mathrm{T} 2$ & $3.94 \pm 1.36^{\mathrm{b}}$ & $3.97 \pm 0.55^{\mathrm{b}}$ & $2.95 \pm 0.27^{\mathrm{b}}$ & $3.43 \pm 0.40^{\mathrm{b}}$ & $3.77 \pm 0.75^{\mathrm{b}}$ & $3.61 \pm 0.98^{b}$ \\
\hline & Mean & $6.35 \pm 1.55^{\mathrm{a}}$ & $5.67 \pm 1.23^{\mathrm{a}}$ & $5.94 \pm 0.70^{\mathrm{a}}$ & $6.82 \pm 0.70^{\mathrm{a}}$ & $6.93 \pm 0.70^{\mathrm{a}}$ & \\
\hline \multirow{3}{*}{ Swollen cells } & $\mathrm{T} 1$ & $4.59 \pm 1.04^{\text {bcde }}$ & $7.16 \pm 1.29^{\mathrm{b}}$ & $5.59 \pm 0.65^{\mathrm{bc}}$ & $5.50 \pm 0.30^{\mathrm{bcd}}$ & $10.02 \pm 2.23^{\mathrm{a}}$ & $6.57 \pm 1.26^{\mathrm{a}}$ \\
\hline & $\mathrm{T} 2$ & $3.39 \pm 0.34^{\text {cde }}$ & $2.83 \pm 0.29^{\mathrm{de}}$ & $2.09 \pm 0.37^{\mathrm{e}}$ & $4.63 \pm 0.32^{\text {bcde }}$ & $4.1 \pm 0.36^{\text {cde }}$ & $3.4 \pm 0.33^{\mathrm{b}}$ \\
\hline & Mean & $3.99 \pm 0.74^{\mathrm{b}}$ & $4.99 \pm 0.79^{\mathrm{b}}$ & $3.84 \pm 0.51^{\mathrm{b}}$ & $5.06 \pm 0.31^{\mathrm{b}}$ & $7.06 \pm 1.26^{\mathrm{a}}$ & \\
\hline \multirow{2}{*}{ Hemolyzed cells } & $\mathrm{T} 1$ & $7.43 \pm 1.11^{\mathrm{a}}$ & $3.70 \pm 0.87^{\mathrm{cd}}$ & $3.27 \pm 0.31^{\text {cde }}$ & $6.40 \pm 1.94^{\mathrm{ab}}$ & $4.17 \pm 0.77^{\mathrm{bc}}$ & $4.99 \pm 1.21^{\mathrm{a}}$ \\
\hline & Mean & $4.00 \pm 0.74^{\mathrm{a}}$ & $2.56 \pm 0.62^{\mathrm{b}}$ & $2.04 \pm 0.24^{\mathrm{c}}$ & $3.81 \pm 1.08^{\mathrm{a}}$ & $2.80 \pm 0.58^{\mathrm{b}}$ & \\
\hline
\end{tabular}

Means carrying same letters do not differ significantly; results are expressed as mean $\pm \mathrm{sd}$; $\mathrm{t} 1$ chlorpyrifos $0.01 \mu \mathrm{l} / \mathrm{l}$; $\mathrm{t} 2$ chlorpyrifos $0.015 \mu \mathrm{l} / \mathrm{l}$.

Table 2. Showing the nucleus morphological abnormalities of fish 1, fish 2 and fish 3 observed against chlorpyrifos $(0.01 \mu \mathrm{L} / \mathrm{L}$ T1, $0.015 \mu \mathrm{L} / \mathrm{L}$ T2) exposure for 3, 6, 9, 12 and 15 days.

\begin{tabular}{|c|c|c|c|c|c|c|c|}
\hline & & \multicolumn{5}{|c|}{ Days } & \multirow{2}{*}{ Mean } \\
\hline & & 3 & 6 & 9 & 12 & 15 & \\
\hline \multirow{3}{*}{ Micronucleus } & $\mathrm{T} 1$ & $1.52 \pm 0.70^{\mathrm{b}}$ & $0.39 \pm 0.21^{\mathrm{b}}$ & $1.45 \pm 0.72^{\mathrm{b}}$ & $1.20 \pm 0.26^{\mathrm{b}}$ & $1.52 \pm 0.33^{\mathrm{b}}$ & $1.22 \pm 0.55^{\mathrm{b}}$ \\
\hline & $\mathrm{T} 2$ & $1.49 \pm 0.17^{\mathrm{b}}$ & $1.80 \pm 0.52^{\mathrm{b}}$ & $1.93 \pm 0.12^{\mathrm{b}}$ & $1.82 \pm 0.57^{\mathrm{b}}$ & $4.23 \pm 1.12^{\mathrm{a}}$ & $2.26 \pm 0.57^{\mathrm{a}}$ \\
\hline & Mean & $1.50 \pm 0.35^{\mathrm{b}}$ & $1.22 \pm 0.35^{\mathrm{b}}$ & $1.70 \pm 0.42^{\mathrm{b}}$ & $1.51 \pm 0.41^{\mathrm{b}}$ & $2.86 \pm 0.73^{\mathrm{a}}$ & \\
\hline \multirow{3}{*}{ Deformed nucleus } & $\mathrm{T} 1$ & $2.74 \pm 0.13^{\mathrm{b}}$ & $5.98 \pm 1.49^{\mathrm{a}}$ & $2.91 \pm 1.11^{\mathrm{b}}$ & $3.46 \pm 0.25^{\mathrm{b}}$ & $3.54 \pm 0.37^{\mathrm{b}}$ & $3.05 \pm 0.59^{\mathrm{b}}$ \\
\hline & $\mathrm{T} 2$ & $3.10 \pm 0.36^{\mathrm{b}}$ & $2.41 \pm 0.16^{\mathrm{b}}$ & $2.77 \pm 0.05^{\mathrm{b}}$ & $3.07 \pm 0.40^{\mathrm{b}}$ & $3.93 \pm 0.12^{\mathrm{b}}$ & $3.72 \pm 0.28^{\mathrm{a}}$ \\
\hline & Mean & $2.92 \pm 0.25^{\mathrm{b}}$ & $4,19 \pm 0.83^{\mathrm{a}}$ & $2.84 \pm 0.58^{\mathrm{b}}$ & $3.27 \pm 0.32^{\mathrm{ab}}$ & $3.74 \pm 0.24^{\mathrm{ab}}$ & \\
\hline \multirow{3}{*}{ Nuclear shift } & $\mathrm{T} 1$ & $3.28 \pm 1.02^{\mathrm{a}}$ & $1.84 \pm 0.97^{\mathrm{ab}}$ & $1.76 \pm 0.32^{\mathrm{ab}}$ & $1.43 \pm 0.71^{\mathrm{b}}$ & $1.32 \pm 0.36^{\mathrm{b}}$ & $1.92 \pm 0.68^{\mathrm{a}}$ \\
\hline & $\mathrm{T} 2$ & $1.53 \pm 0.50^{\mathrm{b}}$ & $0.78 \pm 0.30^{\mathrm{b}}$ & $0.90 \pm 0.50^{\mathrm{b}}$ & $0.94 \pm 0.24^{\mathrm{b}}$ & $1.73 \pm 0.42^{\mathrm{ab}}$ & $1.17 \pm 0.39^{b}$ \\
\hline & Mean & $2.41 \pm 0.76^{\mathrm{a}}$ & $1.31 \pm 0.64^{\mathrm{b}}$ & $1.33 \pm 0.41^{\mathrm{b}}$ & $1.18 \pm 0.48^{\mathrm{b}}$ & $1.53 \pm 0.39^{\mathrm{ab}}$ & \\
\hline
\end{tabular}

Means carrying same letters do not differ significantly; results are expressed as mean $\pm \mathrm{sd}$; $\mathrm{t} 1$ chlorpyrifos $0.01 \mu \mathrm{l} / \mathrm{l}$; $\mathrm{t} 2$ chlorpyrifos $0.015 \mu \mathrm{l} / \mathrm{l}$.

nucleus percentage was significantly affected by treatment, days and their interaction, while in case of nuclear shift, significant effect was observed for the effect of days and treatment and non-significant for their interaction (Table 2).

Results obtained in the present study regarding cellular and nuclear abnormalities depicted dose dependent manner with increased abnormality by increasing the dosage level. Similarly increasing the duration of exposure also increased such abnormalities. Results obtained in the current study are in line with the previous findings that reported increased nuclear abnormalities with increased pesticide exposure (Muranli \& Guner, 2011; Kumar, 2012; Bhatnagar et al., 2016; Ruiz de Arcaute et al., 2016). Kumar (2012), during his study reported an elevated level of red blood cells with micronucleus (MN) and nuclear abnor- 
malities (NA) because of chlorpyrifos exposure in the range of 10.5, 2.5 and 1 $\mu \mathrm{g} / \mathrm{L}$ for a duration of 5 to 25 days in Channa punctatus. Likewise, Bhatnagar et al. (2016) highlighted that when different doses of chlorpyrifos (CPF) were exposed to fresh water fish Cirrhinus mrigala for a time period of 35 days resulted in increased number of red blood cells (RBCs) with micro nuclei and broken eggs nuclear abnormality.

\subsection{Tissue Histopathology}

To find out the diseases in treated group was the main purpose of the study against the toxicological impact of chlorpyrifos. The diseases were found out in fish tissue (brain and liver). Necrosis, degeneration of neuron, vacuolization in the brain tissue while hepatic necrosis, hepatolysis and hepatic vacuolization in the liver tissue of the fish which were treated by chlorpyrifos.

\subsection{Brain Tissue}

Fish was treated against 0.01 and $0.015 \mu \mathrm{L} / \mathrm{L}$ concentrations of chlorpyrifos for 3 , 6, 9, 12 and 15 days and brain tissue was evaluated for following diseases as necrosis, degeneration of neuron and vacuolization. Scores for necrosis, degeneration of neuron and vacuolization of brain tissue for both doses of chlorpyrifos are presented in Table 3. Histopathological examination is an effective way for evaluating the impact of various anthropogenic pollutants on living beings. They can be marked as indicator to reflect the health status of organisms of a specific ecosystem (Khoshnood et al., 2010; Faheem et al., 2016). During present project, it was clearly examined that chlorpyrifos at each dose level resulted in marked changes in brain tissue. The normalized structure of brain tissue can be seen in Figure 2, showing normalized cells with usual structure. The alteration observed after exposing to $0.01 \mu \mathrm{L} / \mathrm{L}$ and $0.015 \mu \mathrm{L} / \mathrm{L}$ of chlorpyrifos appeared in the form of vacuolization, necrotic cells and degenerated neurons (Figure 2).

The degree of damage associated with chlorpyrifos exposure to the brain of

Table 3. Showing alteration scoring of brain and liver tissues against 0.01 and $0.015 \mu \mathrm{L} / \mathrm{L}$ of chlorpyrifos for $0.01 \mu \mathrm{L} / \mathrm{L}$ and 0.015 $\mu \mathrm{L} / \mathrm{L}$ concentrations.

\begin{tabular}{|c|c|c|c|c|c|c|c|c|c|c|c|c|}
\hline \multirow[b]{2}{*}{ S. No } & \multirow[b]{2}{*}{ Tissue } & \multirow[b]{2}{*}{ Disease } & \multicolumn{10}{|c|}{ Scoring } \\
\hline & & & \multicolumn{5}{|c|}{$0.01 \mu \mathrm{L} / \mathrm{L}$} & \multicolumn{5}{|c|}{$0.015 \mu \mathrm{L} / \mathrm{L}$} \\
\hline 1. & & Vacuolization (V) & + & - & - & - & ++ & ++ & ++ & ++ & +++ & ++ \\
\hline 2. & Brain & Degeneration of neuron (DN) & - & + & ++ & +++ & + & +++ & +++ & + & + & + \\
\hline 3. & & Necrosis $(\mathrm{N})$ & - & + & ++ & + & ++ & +++ & +++ & ++ & ++ & + \\
\hline 1. & & Hepatic necrosis (HN) & - & - & + & - & + & + & + & + & ++ & + \\
\hline 2. & Liver & Hepatic vacuolization (HV) & - & + & - & - & - & ++ & ++ & ++ & +++ & +++ \\
\hline 3. & & Hepatolysis $(\mathrm{H})$ & ++ & ++ & +++ & +++ & +++ & ++ & ++ & +++ & +++ & ++ \\
\hline
\end{tabular}

- none; + low; ++ mild; +++ severe. 

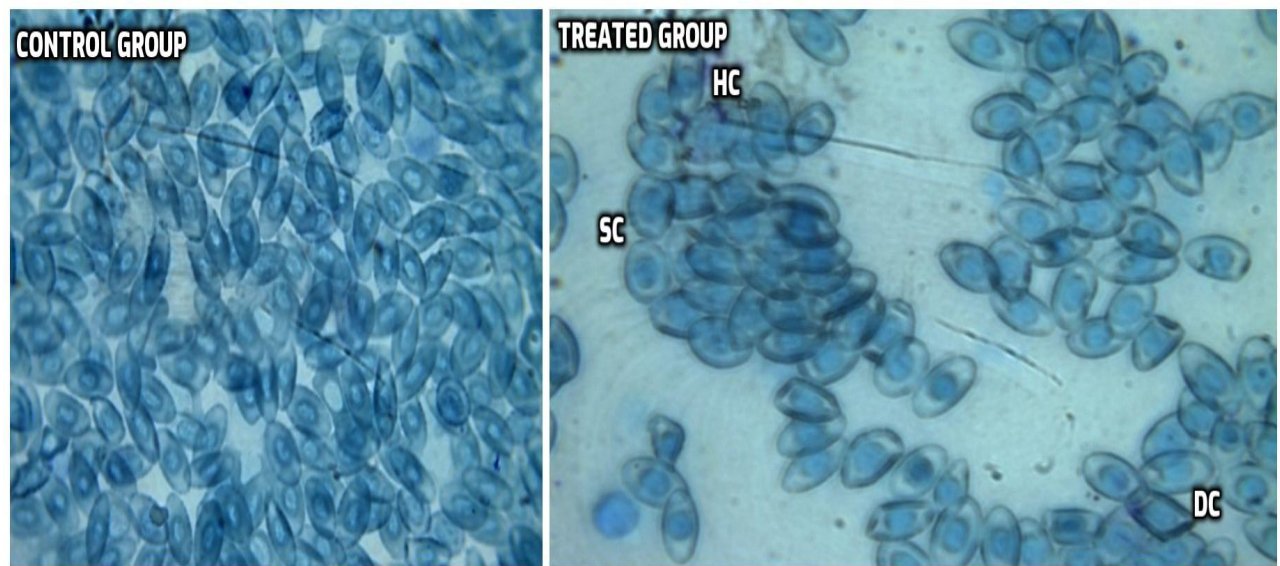

Figure 1. Representing comparison of control and treated group of red blood cells. (HC): Hemolyzed cells; (SC): Swell cells; (DC): Deformed cells.
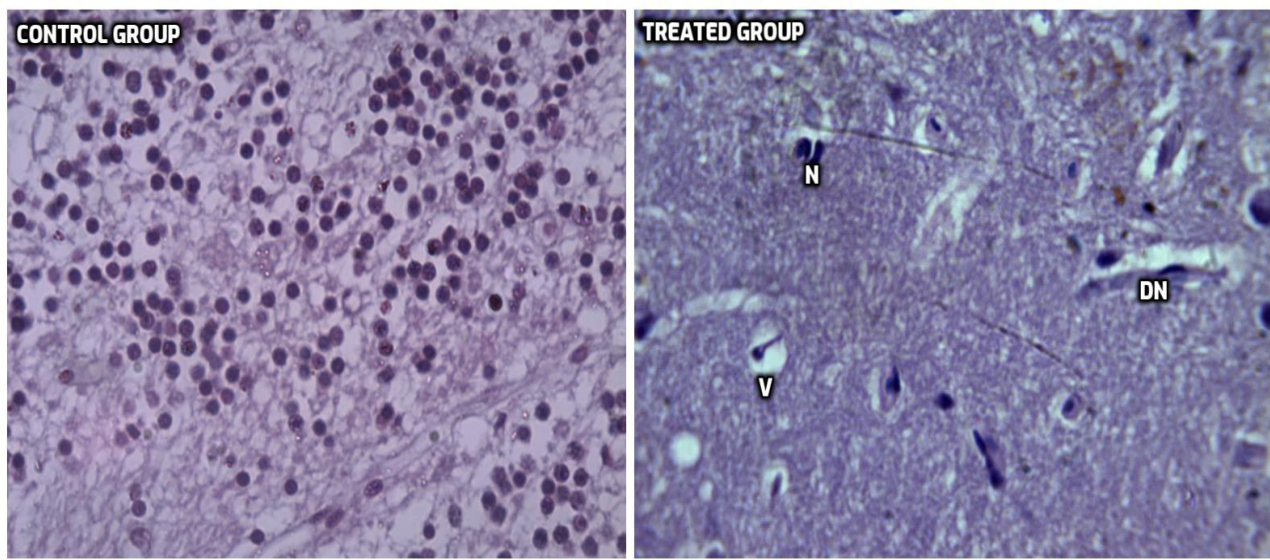

Figure 2. Representing comparison of control and treated group of brain tissues. (V): Vacuolization; (N): Necrosis; (DN): Damage neurons.

fresh water fish was progressive over the duration of exposure. This fact highlighted that histopathological damage is not only linked with the dose of chemical but also depends on the length of exposure (Lakshmaiah, 2017). Different studies have been conducted from time to time to analyze the toxicological impact of such anthropogenic chemicals on aquatic lives (Das \& Subhas, 2000; Ayoola \& Ajani, 2008; Ayoola, 2008; Pugazhvendan et al., 2009). Das and Subhas (2000) analyzed effect of hexachlorocyclohexane exposure at a dose level of 0.35 and $1.73 \mathrm{ppm}$ and observed mild vacuolar alterations in cerebrum changes at the former level while, at the later, severe cerebrum neuronal cells necrosis as well as loss of nissl substance in the brain of the Indian major carp (Labeo rohita) was observed. Ayoola and Ajani (2008), investigated the effect of exposing lethal dose of cypermethrin on the brain of fish Clarias gariepinus, and observed neuronal degeneration, mononuclear infilteration and severe spongiosis. Likewise, similar effects were observed in the brain of fish Oreochromis niloticus i.e. haemorrhage, congestion, spongiosis and mononuclear infilteration, because of the exposure to the fatal dose of glyphosate (Ayoola, 2008). Pugazhvendan et al. 
(2009), analyzed the effect of different doses of Malathion and observed changes such as disintegration, breaking of neural bundles and damage to the brain cells etc.

Different parts of the fish brain are associated with different activities so the damage to any of the part because of such pathological alterations led to the loss of specific function in fishes, which results in changes in normal behavioral and physiological functions of the fish. The behavioral changes are observed in the form of inconsistent swimming, loss of equilibrium and respiratory distress. Other effects observed in rainbow trout due to the exposure of fenvalerate were convulsion and tremors (Thenmozhi et al., 2010; Lakshmaiah, 2017). Hence, the histopathological alterations that took place during the current study because of the exposure to the chlorpyrifos might be responsible for carrying out the normal defense mechanism of the body. Therefore, extended exposure to such anthropogenic chemicals may lead to the loss of these organs and their complete functions.

\subsection{Liver Tissue}

Scores for hepatic necrosis, hepatolysis and hepatic vacuolization in the liver for both doses of chlorpyrifos are presented in Table 3. In the current study, most prominent alterations observed in liver tissue such as hepatic necrosis, hepatolysis and hepatic vacuolization on exposure of 0.01 and $0.015 \mu \mathrm{L} / \mathrm{L}$. As illustrated from Figure 4, fish liver showed a normal texture with typical hepatocytes. Hepatocytes showed normal structure having central nucleus and showing arrangement in the form of cords around central vein. These hepatocytes cords were separated by sinusoids. Upon exposure of chlorpyrifos, several changes were observed in liver hepatocytes. The changes that appear were in dose dependent manner and also showed marked increase with increased time of exposure. Alteration observed by increasing chlorpyrifos concentration were in the form of congested and dilated and central veins, degenerated hepatocytes, necrotic cells, appearance of vacuoles, damaged hepatocytes with eccentric nuclei (Figure 4).
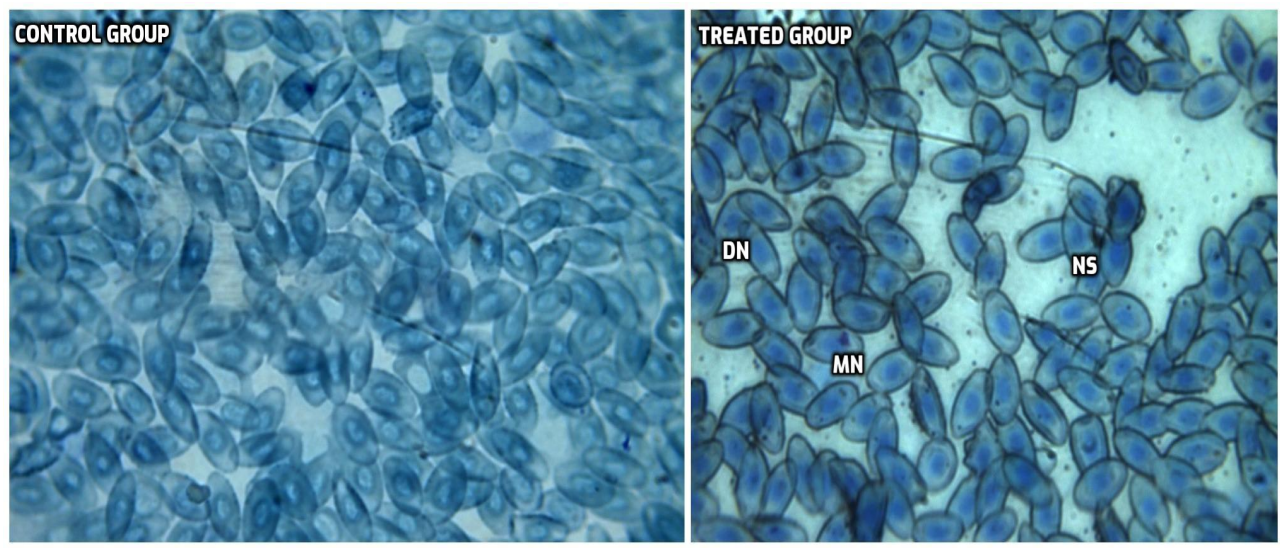

Figure 3. Representing comparison of control and treated group of nucleus of red blood cells. (MN): Micronucleus; (DN): Deformed nucleus; (NS): Nuclear shift. 


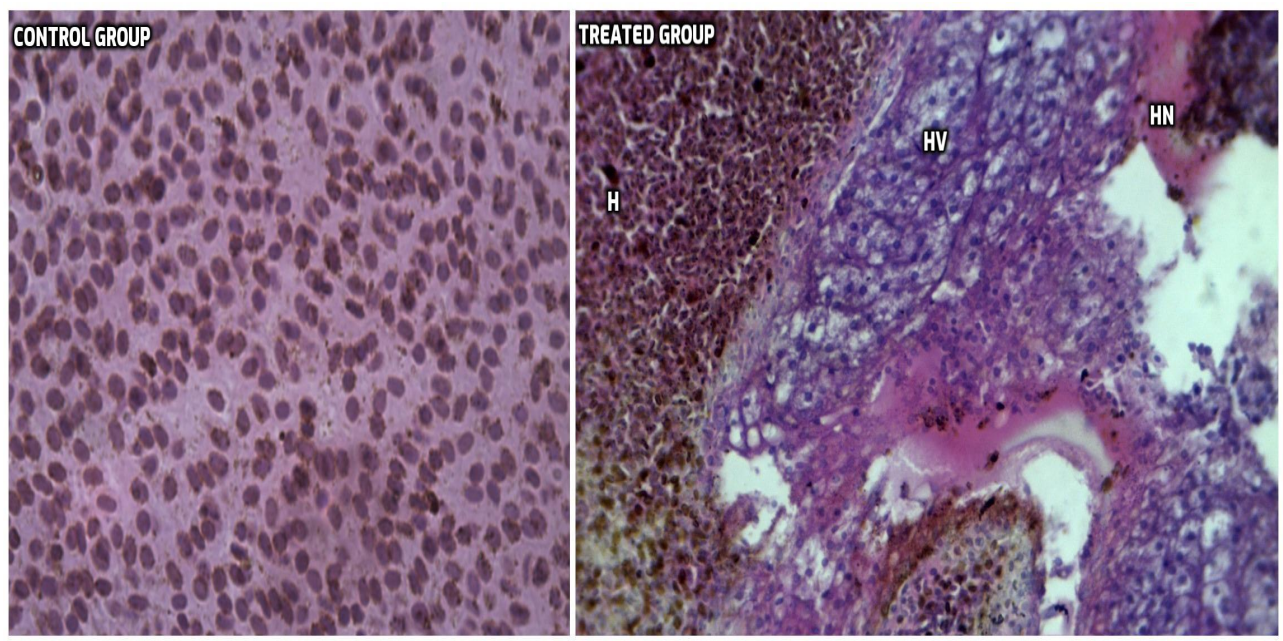

Figure 4. Representing comparison of control and treated group of liver tissues. $(\mathrm{H})$ : Hepatolsis; (HN): Hepatic necrosis; (HV): Hepatic vacuolization.

Similar results have been found previously during different studies for the elucidation of histopathological changes due to anthropogenic chemicals. Fish liver is the chief organ for the detoxification of xenobiotics including chlorpyrifos (Moon et al., 2012). Xing et al. (2012) reported effect of chlorpyrifos and atrazine at doses 1.16 to $116 \mu \mathrm{g} / \mathrm{L}$ and 4.28 to $428 \mu \mathrm{g} / \mathrm{L}$ for 40 days in the form of vacuolization, fatty infilteration and pyknotic nuclei. Devi and Mishra (2013), studies the effect of chlorpyrifos up to a dose level of $15 \mu \mathrm{g} / \mathrm{L}$ on Nile tilapia (Oreochromis niloticus) with $15 \mu \mathrm{g} / \mathrm{L}$ chlorpyrifos. Exposure to $0.538 \mu \mathrm{g} / \mathrm{L}$ and $1.46 \mu \mathrm{g} / \mathrm{L}$ of chlorpyrifos, resulted in hypertrophy of hepatocytes degeneration of hepatocytes (DH), necrosis, nuclear hypertrophy $(\mathrm{NH})$, hepatocellular vacuolation, fibrosis and cytoplasmic vacuolation. Begum and Mithra (2015), estimated deleterious effect of $1.07 \mathrm{ppm}$ malathion on liver of Heteropneustes fossilis for a time period of 21 days. The changes that were observed include vacuoles, hemorrhage and degeneration of hepatocytes. Karmakar et al. (2015) also testified impact of malathion from 10 to $100 \mu \mathrm{g} / \mathrm{L}$ for 10 days in the form of elevated number of pyknotic nuclei. Likewise, Maksymiv et al. (2015) stated that the effect of sencor at a level of $17.4 \mathrm{mg} / \mathrm{L}$ and exposure duration of 4 days led to the degeneration, hypertrophy, and dystrophic lesions in hepatocytes of gold fish (Carrasius auratus).

\section{Conclusion}

The exposure of freshwater fish to the organophosphorus chemicals including chlorpyrifos for an extended period of time may led to the alteration in normal physiological functions in them. Different parts of the fish brain are associated with different activities so the damage to any of the part because of such pathological alterations results in changes in normal behavioral and physiological functions. Fish liver is the chief organ for the detoxification of xenobiotics including chlorpyrifos. Altering liver physiology of water bodies is a reflection of 
aquatic pollution of their habitat. The study demonstrated that the organophosphorus chemicals such as chlorpyrifos at low concentration caused pathology to the fresh water fish and hence can serve as a bioindicator of aquatic ecosystems because of such chemicals.

\section{Conflicts of Interest}

The authors declare no conflicts of interest regarding the publication of this paper.

\section{References}

Ali, F. K., El-Shehawi, A. M., \& Seehy, M. A. (2008). Micronucleus Test in Fish Genome: A Sensitive Monitor for Water Pollution. African Journal of Biotechnology, 7, 606-612.

Anbumani, S., \& Mary, N. M. (2011). Nuclear and Cytoplasmic Abnormalities in the Fish Catla catla (Hamilton) Exposed to Chemicals and Ionizing Radiation. Research Journal of Environmental Sciences, 5, 867-877. https://doi.org/10.3923/rjes.2011.867.877

APHA (1998). Standard Methods for the Examination of Water and Wastewater (920th ed.). Washington DC: American Public Health Association, American Water Works Association and Water Environmental Federation.

$\mathrm{Au}, \mathrm{D}$. W. T. (2004). The Application of Histo-Cytopathological Biomarkers in Marine Pollution Monitoring: A Review. Marine Pollution Bulletin, 48, 817-834. https://doi.org/10.1016/j.marpolbul.2004.02.032

Ayoola, S. O. (2008). Toxicity of Glyphosate Herbicide on Nile Tilapia Oreochromis niloticus Juvenile. African Journal of Agricultural Research, 3, 825-834.

Ayoola, S. O., \& Ajani, E. K. (2008). Histopathological Effect of Cypermethrin on Juvenile African Catfish (Clarias gariepinus). World Journal of Biological Research, 1, 1-14.

Begum, B. H., \& Mithra, D. (2015). Effects of an Organophosphate Pesticide, Malathion (50\% E.C) on the Liver of Air Breathing Fish, Heteropneustes fossilis. International Research Journal of Environmental Sciences, 4, 21-24.

Bell, R. R., Nonavinakere, V. K., \& Soliman, M. R. (2000). Intratracheal Exposure of the Guinea Pig Lung to Cadmium and/or Selenium: A Histological Evaluation. Toxicology Letters, 114, 101-109. https://doi.org/10.1016/S0378-4274(99)00286-6

Bhatnagar, A., Yadav, A. S., \& Cheema, N. (2016). Genotoxic Effects of Chlorpyrifos in Freshwater Fish Cirrhinus mrigala Using Micronucleus Assay. Advances in Biology, 2016, Article ID: 9276963. https://doi.org/10.1155/2016/9276963

Das, B. K., \& Subhas, C. M. (2000). A Histopathological Study of Carp (Labeo rohita) Exposed to Hexachlorocyclohexane. Veterinarski Arhiv, 70, 169-180.

Devi, Y., \& Mishra, A. (2013). Histopathological Alterations in Gill and Liver Anatomy of Fresh Water, Air Breathing Fish Channa punctatus after Pesticide Hilban ${ }^{\circledR}$ (Chlorpyrifos) Treatment. Advances in Bioresearch, 4, 57-62.

Faggio, C., Fedele, G., Arfuso, F., Panzera, M., \& Fazio, F. (2014). Haematological and Biochemical Response of Mugil cephalus after Acclimation to Captivity. Cahiers de Biologie Marine, 55, 31-36.

Faheem, M., \& Khalid, P M. (2017). Oxidative Stress and Histopathologic Biomarkers of Exposure to Bisphenol-A in the Freshwater Fish, Ctenopharyngodon idella. Brazilian Journal of Pharmaceutical Sciences, 53, 1-9. https://doi.org/10.1590/s2175-97902017000317003

Faheem, M., Jahan, N., \& Lone, K. P. (2016). Histopathological Effects of Bisphenol-A on 
Liver, Kidneys and Gills of Indian Major Carp, Catla Catla (Hamilton, 1822). Journal of Animal and Plant Sciences, 26, 514-522.

Giari, L., Simoni, E., Manera, M., \& Dezfuli, B. S. (2008). Histo-Cytological Responses of Dicentrarchus labrax (L.) Following Mercury Exposure. Ecotoxicology and Environmental Safety, 70, 400-410. https://doi.org/10.1016/j.ecoenv.2007.08.013

Gobi, N., Vaseeharan, B., Rekha, R., Vijayakumar, S., \& Faggio, C. (2018). Bioaccumulation, Cytotoxicity and Oxidative Stress of the Acute Exposure Selenium in Oreochromis mossambicus. Ecotoxicology and Environmental Safety, 162, 147-159. https://doi.org/10.1016/j.ecoenv.2018.06.070

Jiraungkoorskula, W., Upatham, E. S., Kruatrachue, M., Sahaphong, S., Vichasri-Grams, S., \& Pokethitiyook, P. (2002). Histopathological Effects of Roundup, a Glyphosate Herbicide, on Nile Tilapia (Oreochromis niloticus). ScienceAsia, 28, 121-127. https://doi.org/10.2306/scienceasia1513-1874.2002.28.121

Karmakar, S., Patra, K., Jana, S., Mandal, D. P., \& Bhattacharjee, S. (2015). Exposure to Environmentally Relevant Concentrations of Malathion Induces Significant Cellular, Biochemical and Histological Alterations in Labeo rohita. Pesticide Biochemistry and Physiology, 126, 49-57. https://doi.org/10.1016/j.pestbp.2015.07.006

Kazi, T. G., Jalbani, N., Baig, J A., Kandhro, G A., Afridi, H. I., Arain, B. M., Jamali, M. K., \& Shah, A. Q. (2009). Assessment of Toxic Metals in Raw and Processed Milk Samples Using Electrothermal Atomic Absorption Spectrophotometer. Food and Chemical Toxicology, 47, 2163-2169. https://doi.org/10.1016/j.fct.2009.05.035

Khoshnood, Z., Khodabandeh, S., Mosafer, S., \& Khoshnood, R. (2010). Effects of Cortisol on Gill Chloride Cells in Persian Sturgeon, Acipenser persicus, Fry. Yakhteh Medical Journal, 11, 424-431.

Kumar, S. P. (2012). Micronucleus Assay: A Sensitive Indicator for Aquatic Pollution. International Journal of Research in BioSciences, 1, 32-37.

Lakshmaiah, G. (2017). Brain Histopathology of the Fish Cyprinus carpio Exposed to Lethal Concentrations of an Organophosphate Insecticide Phorate. International Journal for Advance Research and Development, 2, 668-672.

Majumder, R., \& Kaviraj, A. (2019). Acute and Sublethal Effects of Organophosphate Insecticide Chlorpyrifos on Freshwater Fish Oreochromis niloticus. Drug and Chemical Toxicology, 42, 487-495.

Maksymiv, I. V., Husak, V. V., Mosiichuk, N. M., Matviishyn, T. M., Sluchyk, I. Y., \& Storey, J. M. (2015). Hepatotoxicity of Herbicide Sencor in Goldfish May Result from Induction of Mild Oxidative Stress. Pesticide Biochemistry and Physiology, 122, 67-75. https://doi.org/10.1016/j.pestbp.2014.12.020

McGlashan, D. J., \& Hughies, J. M. (2001). Genetic Evidence for Historical Continuity between Populations of the Australian Freshwater Fish Craterocephalus stercusmuscarum (Atherinidae) East and West of the Great Diving Range. Journal of Fish Biology, 59, 55-67. https://doi.org/10.1111/j.1095-8649.2001.tb01378.x

Metzler, M., \& Erika, P. (2001). Chemistry of Natural and Anthropogenic Endocrine Active Compounds. In M. Metzler (Ed.), The Handbook of Environmental Chemistry, Vol. 3, Part L, Endocrine Disruptors (pp. 63-80). Berlin, Heidelberg: Springer-Verlag.

Moon, M. K., Kim, M. J., Jung, I. K., Koo, Y. D., Ann, H. Y., Lee, K. J., Kim, S. H., Yoon, Y. C., Cho, B. J., Park, K. S., Jang, H. C., \& Park, Y. J. (2012). Bisphenol A Impairs Mitochondrial Function in the Liver at Doses below the No Observed Adverse Effect Level. Journal of Korean Medical Science, 27, 644-652.

https://doi.org/10.3346/jkms.2012.27.6.644

Muranli, F. D. G., \& Güner, U. (2011). Induction of Micronuclei and Nuclear Abnormali- 
ties in Erythrocytes of Mosquito Fish (Gambusia affinis) Following Exposure to the Pyrethroid Insecticide Lambdacyhalothrin. Mutation Research/Genetic Toxicology and Environmental Mutagenesis, 726, 104-108. https://doi.org/10.1016/j.mrgentox.2011.05.004

Oruç, E. (2012). Oxidative Stress Responses and Recovery Patterns in the Liver of Oreochromis niloticus Exposed to Chlorpyrifos-Ethyl. Bulletin of Environmental Contamination and Toxicology, 88, 678-684. https://doi.org/10.1007/s00128-012-0548-4

Ozden, O. (2010). Micro, Macro Mineral and Proximate Composition of Atlantic Bonito and Horse Mackerel: A Monthly Differentiation. International Journal of Food Science \& Technology, 45, 578-586. https://doi.org/10.1111/j.1365-2621.2009.02170.x

Pal, S., Emiko, K., Jiro, K., Seiichi, U., \& Apurba, R. G. (2012). Histopathological Alterations in Gill, Liver and Kidney of Common Carp Exposed to Chlorpyrifos. Journal of Environmental Science and Health, 47, 180-195. https://doi.org/10.1080/03601234.2012.632285

Pugazhvendan, S. R., Jothi, N. N., Kumaran, R. G., Kumaran, S., \& Alagappan, K. M. (2009). Effect of Malathion Toxicity in the Freshwater Fish Ophiocephalus punctatus-A Histological and Histochemical Study. World Journal of Fish and Marine Sciences, 1, 218-224.

Ramah, K. (2011). Histopathological Study on the Effect of Rice Herbicides on Grass Carp (Ctenopharyngodan idella). African Journal of Biotechnology, 10, 1112-1116.

Ruiz de Arcaute, C., Soloneski, S., \& Larramendy, M. L. (2016). Toxic and Genotoxic Effects of the 2,4-Dichlorophenoxyacetic Acid (2,4-D)-Based Herbicide on the Neotropical Fish Cnesterodon decemmaculatus. Ecotoxicology and Environmental Safety, 128, 222-229. https://doi.org/10.1016/j.ecoenv.2016.02.027

Samantha, S., Mitra, K., Chandra, K., Saha, K., Bandopadhyaya, S., \& Ghosh, A. (2005). Heavy Metals in Water of the Rivers Hoogley and Haldi and Their Impact on Fish. Journal of Environmental Biology, 26, 517-523.

Stalin, A., Palani, S., Subramanian, M., Bilal, A. P., Mohammad, K. A., Varadharajan, G., \& Mohamed, S. M. (2019). Impact of Chlorpyrifos on Behavior and Histopathological Indices in Different Tissues of Freshwater Fish Channa punctatus (Bloch). Environmental Science and Pollution Research, 26, 17623-17631.

https://doi.org/10.1007/s11356-019-05165-3

Steel, R., Torrie, J., \& Dieky, D. (1997). Principles and Procedures of Statistics (3rd ed.). New York: McGraw Hill Book Co. Inc.

Sumpter, P. J. (2002). Endocrine Disruption in the Aquatic Environment. In M. Metzler (Ed.), The Handbook of Environmental Chemistry, Vol. 3, Part M, Endocrine Disruptors (pp. 271-289). Berlin, Heidelberg: Springer-Verlag.

Thenmozhi, C., Vignesh, V., Thirumurugan, R., \& Arun, S. (2010). Impacts of Malathion on Mortality and Biochemical Changes of Freshwater Fish Labeo rohita. Iranian Journal of Environmental Health Science \& Engineering, 8, 189-198.

Topal, A., Muhammed, A., Ertan, O., Yeliz, D., Şükrü, B., \& Alparslan, I. (2014). In Vivo Changes in Carbonic Anhydrase Activity and Histopathology of Gill and Liver Tissues after Acute Exposure to Chlorpyrifos in Rainbow Trout. Arhiv za Higijenu Rada i Toksikologiju, 65, 377-385.

Tripathi, M., Mishra, R. P., \& Girdoniya, V. (2011). Histopathological Changes in Liver of a Teleost Fish Catla catla Treated with 1.2\% Lindane. Journal of Fisheries and Aquaculture, 2, 17-19.

Velmurugan, B., Mariadoss, S., Elif, I. C., \& Erhan, U. (2009a). Histopathological Changes in the Gill and Liver Tissues of Freshwater Fish, Cirrhinus mrigala Exposed to Dich- 
lorvos. Brazilian Archives of Biology and Technology, 52, 1291-1296.

https://doi.org/10.1590/S1516-89132009000500029

Velmurugan, B., Selvanayagam, M., Cangiz, E., \& Unlu, E. (2007). The Effects of Monocrotophos to Different Tissues of Fresh Water Fish Cirrhnus mrigala. Bulletin of Environmental Contamination and Toxicology, 78, 450-454.

https://doi.org/10.1007/s00128-007-9190-y

Velmurugan, B., Thresia, M., \& Elif, I. C. (2009b). Histopathological Effects of Cypermethrin on Gill, Liver and Kidney of Fresh WATER fish Clarias gariepinus Burchell, 1822, and Recovery after Exposure. Environmental Technology, 30, 1453-1460. https://doi.org/10.1080/09593330903207194

Xing, H., Li, S., Wang, Z., Gao, X., Xu, S., \& Wang, X. (2012). Oxidative Stress Response and Histopathological Changes Due to Atrazine and Chlorpyrifos Exposure in Common Carp. Pesticide Biochemistry and Physiology, 103, 74-80.

https://doi.org/10.1016/j.pestbp.2012.03.007

Zahran, E., Risha, E., \& Awadin, W. (2018). Acute Exposure to Chlorpyrifos Induces Reversible Changes in Health Parameters of Nile Tilapia (Oreochromis niloticus). Aquatic Toxicology, 197, 47-59. https://doi.org/10.1016/j.aquatox.2018.02.001 